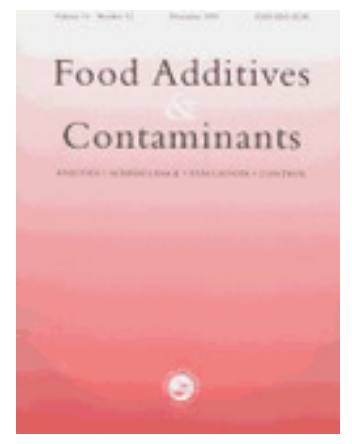

\title{
Core food of the French food supply: 2 nd Total Diet Study
}

\begin{tabular}{|c|c|}
\hline Journal: & Food Additives and Contaminants \\
\hline Manuscript ID: & TFAC-2008-274.R1 \\
\hline Manuscript Type: & Original Research Paper \\
\hline $\begin{array}{l}\text { Date Submitted by the } \\
\text { Author: }\end{array}$ & 08-Dec-2008 \\
\hline Complete List of Authors: & $\begin{array}{l}\text { Sirot, Véronique; French Food Safety Agency } \\
\text { Volatier, Jean-Luc; French Food Safety Agency, Office of Scientific } \\
\text { Support for Risk Assessment } \\
\text { Calamassi-Tran, Gloria; French Food Safety Agency, Observation } \\
\text { Center for Food Consumption } \\
\text { Dubuisson, Carine; AFSSA, PASER/OCA; French Food Safety } \\
\text { Agency, Observation Center for Food Consumption } \\
\text { MENARD, Céline; French Food Safety Agency, Quantitative Risk } \\
\text { Assessment Team } \\
\text { Dufour, Ariane; French Food Safety Agency, Observation Center for } \\
\text { Food Consumption } \\
\text { Leblanc, Jean-Charles; French Food Safety Agency, Quantitative } \\
\text { Risk Assessment Team }\end{array}$ \\
\hline Methods/Techniques: & Total diet studies \\
\hline Additives/Contaminants: & $\begin{array}{l}\text { Environmental contaminants, Pesticide residues, Process } \\
\text { contaminants, Trace elements }\end{array}$ \\
\hline Food Types: & Beverages, Cooked foods \\
\hline
\end{tabular}

\section{SCHOLARONE Manuscripts}




\title{
Core food of the French food supply: $2^{\text {nd }}$ Total Diet Study
}

Sirot $\mathrm{V}^{\mathrm{a}, \star}$, Volatier $\mathrm{JL}^{\mathrm{a}}$, Calamassi-Tran $\mathrm{G}^{\mathrm{a}}$, Dubuisson $\mathrm{C}^{\mathrm{a}}$, Ménard $\mathrm{C}^{\mathrm{a}}$, Dufour $\mathrm{A}^{\mathrm{a}}$ and Leblanc $J C^{a}$

${ }^{a}$ Agence Française de Sécurité Sanitaire des Aliments (French Food Safety Agency), Maisons-Alfort,

France

*Corresponding author, Email : $\underline{\text { v.sirot@afssa.fr }}$

\begin{abstract}
As first described in the 1980s, the core food intake model allows a precise assessment of dietary nutrient intake and dietary exposure to contaminants insofar as it reflects the eating habits of a target population and covers the most important foods in terms of consumption, selected nutrient and contaminant contribution. This model has been used to set up the sampling strategy of the second French Total Diet Study (TDS) with the aim of obtaining a realistic panorama of nutrient intakes and contaminant exposure for the whole population, useful for quantitative risk assessment. Data on consumption trends and eating habits from the second French individual food consumption survey (INCA2) as well as data from a 2004 purchase panel of French households (SECODIP) were used to identify the core foods to be sampled. 116 core foods on a national scale and 70 core foods on a regional scale were selected according to (i) the consumption data for adults and children, (ii) their consumer rates, and (iii) their high contribution to exposure to one or more contaminants of interest. Foods were collected in 8 French regions (36 cities) and prepared "as-consumed" to be analysed for their nutritional composition and contamination levels. 20,280 different food
\end{abstract}


products were purchased to make up the 1,352 composite samples of core foods to be analysed for additives, environmental contaminants, pesticide residues, trace elements and minerals, mycotoxins and acrylamide. The establishment of such a sampling plan is essential for effective, high-quality monitoring of dietary exposure from a public health point of view.

Keywords: Core food; Total diet study; Dietary exposure assessment. 


\section{Introduction}

In order to assess dietary intake of components of interest, whether nutrients or contaminants, researchers need to have access to recent data on the composition of representative foods consumed by the population they are studying (WHO/ANFZA/FAO, 2002; WHO/INRA, 2004; WHO/CCDCP, 2006). In theory, the best method involves purchasing the foods people eat and analysing these foods. However, the limiting factor is the number of foods which can be provided in terms of costs and the analytical capacities of the laboratory conducting the analyses. The core food approach was first described in 1982 by the US Total Diet Study (TDS) (Egan et al, 2007; Pennington, 1983) and was also used in the first French TDS (Leblanc et al, 2005a). The aim is to identify the foods that are most consumed by the study population (in terms of quantity) and which contribute the most to energy and nutrient intake. These foods are sampled and analysed for the purposes of exposure assessment.

The main steps in the core model are: (i) identify the core foods using national consumption surveys; (ii) assess the mean daily or weekly intake of the core foods using national consumption surveys or other databases; (iii) sample the selected foods, prepare them "as usually consumed by the population" (i.e. prepared and cooked as by the average consumer) and then analyse them for nutrients and contaminants; and (iv) match consumption data and the analytical data to assess nutrient intakes and exposure to contaminants (Egan et al., 2007; Pennington et al, 2002).

\section{The French TDS}

In 1999, the first French TDS was conducted by the French National Institute for Agricultural Research (INRA) in collaboration with the French Food Safety Agency (AFSSA). It focused on exposure to trace elements and minerals, as well as mycotoxins, because of limited its 
budget and because these substances were, at the time, top priority in terms of risk management by the Ministry. The consumption survey used to determine the core foods and to estimate food intake was the National Individual Dietary Consumption (INCA1) survey in 1999. Three hundred thirty-eight core foods (including 25 vegetarian foods) were included and sampled in 3 different urban areas: Paris (the capital), Lyon in the Rhone-Alpes SouthEast region and Lorient in Brittany. Samples were prepared as-consumed and analysed for 18 trace elements and minerals (Leblanc et al, 2005b), plus the main mycotoxin groups (Leblanc et al, 2005a). The aim was to obtain an accurate and realistic view of mineral intakes and exposure to contaminants for the purposes of quantitative risk assessment. Six years after this study, AFSSA initiated a second TDS, called "TDS2", based on new consumption data from the INCA2 survey conducted in 2006 and 2007. This individual food consumption survey includes 2,058 French subjects who were interviewed from December 2005 to March 2006, including 1,519 adults aged 18 to 93 (869 women and 650 males) and 539 children aged 3 to 17 . Subjects were asked to complete a seven-day food record diary (consecutive days) validated in a pilot survey (Lafay et al, 2002) as well as other questionnaires on home cooking habits, anthropometrical and socio-economical factors. The consumed quantities were estimated by several methods:

(i) comparison with photographs compiled in a manual adapted from the SuViMax picture booklet (Le Moullec et al., 1996);

(ii) directly if the quantity is known ( $\mathrm{g}$ or $\mathrm{ml})$;

(iii) number of spoonfuls;

(iv) number of portions.

The record diary and the questionnaires were directly completed by the interviewee after a briefing by a specialist interviewer to ensure correct understanding of food definitions and consistent implementation of the results. 
A specific feature of this second TDS is that it concerns fewer core foods than the first TDS while covering more regions in order to give priority to regional diets because of possible differences in regional contamination levels. The eight large regions are those defined in the INCA2 survey: (i) West (Brittany, Pays de Loire, Poitou-Charentes), (ii) North (Lower Normandy, Upper Normandy, Nord-Pas de Calais, Picardy), (iii) Paris Region (lle de France), (iv) North-East (Champagne Ardennes, Lorraine, Alsace), (v) East (Franche-Comté, Rhône Alpes), (vi) South-East (Provence Alpes Côte d'Azur, Languedoc Roussillon), (vii) South West (Midi-Pyrénées, Aquitaine), and (viii) Center (Centre, Burgundy, Limousin, Auvergne). That means that the sampling was performed in each of these regions as described below, in order to study exposure for adults over 18 years and for children of 3-17 years.

\section{Components of the TDS2}

According to the different updated data on exposure assessment, provided by the Scientific Committees of AFSSA and due to a higher budget allocation, this second French TDS includes more contaminants than the first one. The same 6 trace elements (As, $\mathrm{Pb}, \mathrm{Cd}, \mathrm{Al}$, $\mathrm{Hg}, \mathrm{Sb})$ and 14 minerals ( $\mathrm{Cr}, \mathrm{Ca}, \mathrm{Mn}, \mathrm{Mg}, \mathrm{Ni}, \mathrm{Cu}, \mathrm{Zn}, \mathrm{Li}, \mathrm{Na}, \mathrm{Mo}, \mathrm{Co}$, Se plus $\mathrm{K}$ and $\mathrm{Fe}$ which have been added) will be analysed by the National Reference Laboratory for heavy metals in order to follow trends between 2004 and 2007-2008. Each analysis must be conducted in duplicate to ensure internal quality control (IQC). Mycotoxin content (Aflatoxins $B G$ \& $M$, ochratoxin $A$, patulin and Fusarium mycotoxins (trichothecenes $A$ \& $B$, zearalenone \& nivalenol) will also be assessed in the same way as in the first TDS except for $\mathrm{T}_{2}$-toxin and $\mathrm{HT}_{2}$-toxin where lower analytical limits will be used. Pesticides (organophosphorus \& organochlorine pesticides, carbamates, etc) have been added following a two-year study conducted by AFSSA, using the conservative approach recommended by WHO (WHO, 1997; Menard et al, 2008) to give priority to pesticide residues. According to international guidelines, the average Theoretical Maximum Daily Intake (TMDI) was calculated for each pesticide for the French population by multiplying consumption level by the maximum residue 
limits (MRL) recorded in AFSSA database and updated using European Directives and/or French decrees (Menard et al, 2008). The individual TMDIs were averaged for the French population and expressed as a percentage of ADI (Acceptable Daily Intake). Seventy-two priority pesticides were selected to be analysed: (i) 56 because their TMDI exceeds $80 \%$ of the ADI; (ii) 6 were included because they are in the Stockholm list (European Commission, 2004); (iii) 7 were included because they are in the Gems Food list (WHO, 1999); and (iv) 3 because of their priority identified in the Pesticide Residues National Surveillance System report (taking into account toxicological parameters, environmental fate assessment parameters, contamination level in water and availability of data in food) (AFSSA, 2004).

Analysis of foods "as normally consumed" is important, as preparation (peeling, washing, cooking, etc.) is known to play a key role in lowering the pesticide residue levels in processed/cooked foods. Persistent organic pollutants (Dioxins, PCBs, PAHs, PBBs, PBDEs, etc.) have also been added, taking into account their toxicity as well as the lack of data. Phytoestrogens (isoflavones, coumestans, isoflavane, enterolignans) will be analysed in view of their estrogenic activity, pointed out by the Human Nutrition Scientific Committee of AFSSA. Acrylamide has also been added to the list of analysed contaminants as the Joint FAO/WHO Expert Committee on Food Additives (JECFA) has shown that the safety margin for children is very low concerning the carcinogenic toxicity of this neo-formed substance. At least four food additives were also considered, given the lack of French data and the conclusion of the last review carried out at national level, which highlighted a potential risk of excess ADI for 3 additives (Bemrah et al, 2008): rocou (E160B), sulphites (E220, E221, E222, E223, E224, E226, E227 and E228) and nitrites (E240 and E250). Tartaric acid (E334) was added to this list because there were not enough available French data to carry out an assessment.

Trace elements, minerals and pesticides will be analysed in all samples. The other contaminants will be analysed in all the known contributors to the exposure, or in foods for which more information is needed about contamination. 
This paper presents the methodology and results of the selection of core foods forming the basis of the second French Total Diet Study, which is a major step forward in the assessment of mineral intakes and contaminant exposure among populations.

\section{Materials and methods}

\section{Selection of core foods}

Nine lists of foods have been established: one national and eight regional. The national list includes 116 processed foods which are likely to present homogeneous contamination levels with respect to production and/or processing methods, following the sampling strategy of the first French TDS and of TDSs from other countries like New Zealand (NZFSA, 2006). This group includes foods which are produced and processed by a limited group of manufacturers, such as breakfast cereals, some beverages, ready-to-eat dishes, tropical fruits, cookies, etc. The regional foods include 70 non-processed foods which are likely to present heterogeneous contamination levels due to production methods, animal feed and/or environmental factors. These lists include foods such as eggs, meat, meat products, fish, fruit and vegetables from mainland France.

Two main criteria have been considered for the inclusion of an individual food in the lists: (i) the most consumed foods in terms of quantity (grams per week) for adults and children and at least $5 \%$ of the consumer rate for adults and/or children, and (ii) foods which are known to contribute the most exposure to one or more contaminants of interest.

Criterion (i): Each regional list included the first 30 individual foods corresponding to the most consumed products having at least $5 \%$ of consumers among adults and/or children (consumption data from the INCA2 survey, based on 812 foods items or individual foods gathered in 44 food groups). For the regional lists, only the consumption data from people 
whose main residence was located in the region considered were taken into account. For the national list, the first 90 foods were those that were the most consumed products for adults and children. For the national list, consumption data of the entire study population were taken into account. Child and adult consumptions were studied separately insofar as some products are known to be consumed mostly by one group or another and a product representing a significant part of the child diet might not have been selected through the adult diet.

Criterion (ii): The main contributors to exposure to the contaminants of interest were added if they had not been selected during the first stage. For mycotoxins and trace elements, the main contributors were identified through the results of the first French TDS (Leblanc et al, 2005a; 2005b). For phytoestrogens, persistent organic pollutants and additives, the main contributors were identified through the scientific literature and through the risk assessment performed by the AFSSA Scientific Committees (Bemrah et al, 2008; Tard et al, 2008; AFSSA, 2005b). The main contributors to the French population's exposure to pesticides were selected, representing at least $5 \%$ of the total contribution. This $5 \%$ corresponds to the criterion established by the WHO Codex Alimentarius Commission in its Procedural Manual for maximum limits in foods or food groups contributing significantly to the tolerable daily or weekly intake (CAC, 2005). It involves 51 foods, including meat products, cereals, fruit and vegetables and dairy products, which were added to the TDS national and regional lists if they were not already included during the initial stages.

\section{Specifications of the individual food composite samples}

When insufficient data was available from the INCA2 dietary survey, the data from the SECODIP-TNS purchase panel of 2004 (a marketing panel of about 17,150 French households, unpublished data) were used. 


\section{1}

Each of the samples from the lists is composed of up to 15 sub-samples of equal weight of the same food item (Table 1, Figure 1), so that this strategy is based on individual food samples instead of food group samples. Fifteen sub-samples provide a confidence interval (IC) between $15-25 \%$ for the mean analysed composition or contamination value, according to the formula: $I C=1.96 \times S D / \sqrt{ }(n)$, where $S D$ is the standard deviation (ranging $30-50 \%$ of the mean) and $\mathrm{n}$ is the number of sub-samples.

The sub-samples were chosen on the basis of five levels of composition completely describing each item (Table 1). The first level of composition of the item was the quantity consumed, especially for grouped core foods. The second level was the texture or the manufacturing process. The third level was the fat, salt or other component content when it was necessary, i.e. for cheese (fat content), meat (fat content), butter (salt content), chocolate (cocoa content), etc. The fourth level of composition was the flavor and/or origin. The fifth and final one was the product specifications such as "light", "organic", "fortified with vitamins", "fortified with calcium", etc.

As a next step, the sub-samples were chosen on the basis of: place of purchase (large and medium outlets, market, etc.), preservation method (fresh, frozen, canned, etc.) and brands. For industrial products, composite samples were composed of sub-samples based on the brands recorded in the INCA2 interviews or, when data were insufficient, on the market shares from the 2004 SECODIP-TNS purchase panel (unpublished data). Choice of nonindustrial products, e.g. fruit varieties was based on the same decision rules.

\section{Methodology of sample collection}

Core foods were collected between June 2007 and January 2009 (Table 2) by professional buyers. Regional core foods were purchased in each of the eight large regions described above. National core foods were purchased in Paris and its suburbs because of the availability of foods in all seasons. 
In each of the eight regions, four cities were chosen to sample the regional core foods. The main criteria for inclusion of a city were the number of inhabitants according to the results of the National Institute for Statistics and Economic Studies (INSEE, 1999) and the distance between the four cities selected in a same region. Two pairs of cities were formed in each region by selecting cities as far as possible from each other to assure different channels of food supply, especially for fresh products such as fruits and vegetables (Table 2). Core foods were collected twice during the study, the first time in the first pair of cities and the second time in the second pair. Each sampling period lasted 3 months at the most and the start dates of the two periods were spaced at least six months apart to cover potential variability in the contamination and composition levels between seasons, and to take into account seasonal purchases such as certain fruit or vegetables, as well as meat cuts. For each region, samples were therefore collected in summer and winter, or in autumn and in springtime. The order of regions in the sampling and the first pair for each region were chosen at random.

Outlets for retailer brands were chosen by their presence in the sampling plan. For other products, outlets were chosen according to their location in the cities visited.

A procedure was put into place for cases when products were not found on the market during the sampling period. For example: when a brand available in 2004 was no longer available, the corresponding brand from the same manufacture was chosen; when there was no equivalent brand from the same manufacture, the next brand according to the market shares was chosen; when a brand was not available in a specific region or city, the most common similar brand in the supermarket was selected. As the main aim of the study was to reflect consumption in France, priority was given to the most representative product or the product put in a prominent place in sales outlets. 


\section{Food preparation "as-consumed"}

For each product, only the edible part was used to prepare the sample, i.e. inedible parts (bones, fish skin, shells, seeds, inedible peels, etc.) were removed. Then the core foods were prepared as-consumed, i.e. as prepared by the average consumer. For example, fruit and vegetables were rinsed. Vegetables, meat and fish products were cooked when applicable (braised, grilled, roasted, fried, backed, etc.). The distribution of the methods of cooking the sub-samples was determined proportionally to what was reported during the interviews of the INCA2 dietary survey for each food. For each sub-sample the preparation was specified with pre-cooking preparation, cooking with time when applicable, and postcooking preparation (boning the meat and adding salt, oil or vinegar). Some of the most commonly consumed products were chosen to prepare the other products, e.g. semiskimmed milk and cooking fat such as olive oil, sunflower oil or unsalted butter. The brands of these products were selected according to their market shares.

Composite dishes (e.g. couscous, pot-au-feu, home-made cakes) were prepared according to the most common recipes chosen from popular French websites.

\section{Data analyses}

All data analyses were performed using Microsoft Office Access (Microsoft Corporation, Redmond, WA, USA) and SAS version 8.02 (SAS Institute Inc., Cary, NC, USA). 


\section{Results and discussion}

\section{Regional core foods}

Table 3 presents the results of the selection of the regional core foods. For each selected core food, the Table 3 (as well as the Table 4) shows the adult and child consumer rates and the contribution of the food in the total average diet. For each food, the number of regions sampled is also indicated.

The first 30 selected foods are the most consumed in terms of quantity for adults and/or children, and concern more than $5 \%$ of consumers in at least one of the groups. The first list of 30 core foods only covers about $80 \%$ of total diet for regional foods among adults and children. Beverages represent the most consumed regional foods. Tap water represents on average $23.5 \%$ and $24.2 \%$, respectively, of consumption in terms of quantity, with $72.1 \%$ and $79.7 \%$ of consumers in each group. Semi-skimmed milk and spring water also contribute to more than $10 \%$ of children's diets ( $14.8 \%$ and $11.2 \%$ respectively).

Nine cooked vegetable samples were added to the above regional lists because of their contribution to pesticide exposure, despite their very low consumption levels (less than 2 g/day): courgettes, globe artichokes, cauliflowers, Belgian endives, spinach, onions, corn, leeks and turnips. Pears, strawberries, cherries and grapes were added for the same reason. Pork-based products such as pâté, raw ham, chipolata-type sausages and pork fats were added to the lists because of the contribution of pork to exposure to pesticide (Menard et al, 2008) and mycotoxins and their potentially high level of additives. One sample of liver was chosen, given the well-known contribution of offal to exposure to contaminants such as cadmium, POPs and some mycotoxins. Potato-crisps were sampled because of their contribution to acrylamide exposure, especially among children, $23.9 \%$ of whom consume 


\begin{abstract}
this product. Mussel and shrimp were added for their contribution to cadmium, arsenic and POP exposure (Leblanc et al, 2006).
\end{abstract}

With these additions, regional list covers $86.7 \%$ to $88.7 \%$ of the diet for regional core foods among adults and $87.9 \%$ to $91.2 \%$ for the children, which is close to the first TDS coverage, notably thanks to the food grouping, but concerning many more regions.

Fifty-three core foods are common to the 8 regions. They correspond to standard consumption. On the other hand, 22 core foods are found in only one, two or three regions. Except for apricot, which is an exception due to its short growing season, the differences between the regional lists resulted from differences in consumption patterns between regions, such as paella and duck, which are mainly consumed in the Midi-Pyrenees and Aquitaine regions, or other regional dishes such as Cassoulet or Sauerkraut with meat. For some products, differences could be explained by regional dietary habits. For instance, in the South-east region of France, skimmed milk appeared to be one of the most consumed foods, especially among adults, with $7.2 \%$ of consumers, representing $0.8 \%$ of the total diet (details not presented). In the Parisian region, skimmed milk is consumed by only $4.2 \%$ of the adults and $2.3 \%$ of the children, representing $0.5 \%$ and $0.1 \%$ respectively of the diet. This means that skimmed milk did not feature as one of the most consumed foods in the latter region. Other differences between the regional lists were due to differences in place of purchase (large and medium outlets, market, etc.), preferred preservation method (fresh, frozen, canned, etc.) and brands. Purchases in open markets represent $3 \%$ of foods in Southern region and $2 \%$ of foods in Parisian region. In the Parisian region, $2 \%$ of products were bought in fast-food chains versus only $0.8 \%$ in the South-east region. Concerning the preservation method, $12 \%$ of foods were bought frozen in the Parisian region versus $8 \%$ in the South-east region.

National core foods 
Table 4 presents the results of the selection of national core foods. The first 90 selected foods, i.e. the most consumed in terms of quantity and by more than $5 \%$ of consumers, cover $80.4 \%$ of total diet among adults and $80.3 \%$ among children. French breads (baguette), wine and sodas represent the most consumed core foods among adults, making up $7.9 \%, 7.0 \%$ and $5.1 \%$ respectively of the diet. Among children, sodas $(7.8 \%$ of the diet), orange juice (6.3\%), French breads and pasta (both 5.8\%) are the most consumed foods. As expected, beverages (water, soft drinks and alcohols) represent one third of the consumption of national foods in terms of quantity: $37.2 \%$ for adults and $29.7 \%$ for children.

According to these results, three core foods are consumed by adults and not by children: pastis, tofu and soybean oil. As pastis is an aniseed-flavored alcoholic beverage, it is not be surprising that no children in the study consumed it. Nine soy-based products were included in the national list because of their renowned high phytoestrogen level: soy sauce, soymilk, soybean oil, some soy-based creams, imitation meat, canned bean sprouts, tofu, etc. These products are consumed by $1.5-2.0 \%$ of the population, more adults than children, which is not negligible. Moreover, the inclusion of such products could allow assessment of exposure to contaminants of particular subgroups of the population such as vegetarians or vegans, who are known to consume these products and who are very rarely targeted in studies. In addition, few composition and contamination data are presently available about these increasingly consumed products.

Margarine, pineapple juice and some other products were added for their known high level of at least one of the four additives studied.

In total, 26 foods were added, and the national list now covers $82.4 \%$ of the diet for national core foods among adults and $83.7 \%$ for the children. Coverage is lower compared with the first TDS, but reducing the number of foods provides a cost benefit allowing additional analyses. 


\section{Advantages and risks of this strategy}

The number of sub-samples in a core food, i.e. 15 products, does not seem to be too high insofar as contamination or composition levels are not diluted. And this number does not seem so low that the consumed food is poorly represented. However, one should bear in mind that the dilution effect is avoided in the particular case of an assessment of long-term exposure, which is the case in a total diet study. This specific sampling method is neither appropriate for short-term exposure calculations nor for specific at-risk population groups with particular dietary habits that may lead to a systematic over-exposure such as subsistent consumers with limited supply sources. Short-term exposure could imply highly contaminated products for ad hoc consumptions. For specific at-risk populations with limited food supply sources, sampling composed of fewer sub-samples may be more appropriate because of a lower dilution of potential high contamination, unless the contamination value is validated by data from the scientific literature or national food monitoring plan. Moreover, this sampling provides only two averaged weighted values of contamination level for each contaminant (one per season in this case). It is not relevant for probabilistic exposure assessment, which requires at least ten values to ensure a random trial.

One of the main advantages of this sampling strategy is its intermediate cost due to pooled samples, while covering most core foods. It is better than the strategy of choosing one representative food in a group, for instance orange for citrus fruits, because the composite samples take more foods from the group into account. Representativeness is achieved through proportionality, and each sample is then more similar to what is actually consumed by the studied population. Actual consumption data are used to construct the sample plan, as well as brand market shares and individual consumption habits (home-made, industrial, etc.). The same data will be used to assess the exposure of the population, and consumption data will be compared with contamination data of samples coming from the region of each subject. 
Moreover, international committees recommend choosing a sampling strategy that includes composite samples based on individual core foods rather than food groups (WHO/CCDCP, 2006). Compared with foreign TDS sampling strategies, the number of total samples is in the current range of other TDSs (Table 5), except for the UK, where sampling is based on food group samples (Peattie et al, 1983). The French TDS has the highest number of purchased products, due to the number of sub-samples in each composite sample, which ensures a good representativeness of the market share of the products and the purchasing habits of the population.

The Canadian TDS recently included ethnic food insofar as 200,000 immigrants arrive in Canada each year. These kinds of food are not available in our sampling plan for two reasons. The first is that in the national food survey, ethnic foods are not well covered because of a low yearly consumption, despite a large population of foreign origin. Most ethnic foods are still considered to be occasional foods and are not available everywhere, except in the capital and in big cities. The second reason is that the food survey does not take into account precisions such as "halal" or "kosher".

The French sampling plan also takes the seasonal nature of products into account, while the Canadian TDS, for instance, does not, even though seasons could highly impact the contamination data, for example concerning pesticide residues or mycotoxins, the use of which depends on climate conditions.

The choice of 36 cities in eight different regions ensures good representativeness of the different regional food habits in France. Considering the high diversity of the French diet, this sampling plan could be applied to all countries with a lower or comparable diversity.

Such a sampling strategy is also used in other French studies. For instance, the Oqali (Observatory of food quality) is studying the public health impact of improvements in 

1

nutritional compositions of industrial foods. This requires representative sampling and product analysis. Part of the TDS sampling strategy has thus been used and re-adapted for the needs and aims of the Observatory. For each chosen food, four composite samples are created, i.e. one for each market sector (branded goods, supermarket brand goods, discount goods and low-price goods). Each composite sample is made up of sub-samples, according to the market shares of each brand (data from the French SECODIP panel).

\section{Conclusions}

Compared with the 1999-2001 study, the present French TDS covers about 140 fewer products, but in view of the coverage of the average total diet ( $90 \%$ for the first TDS, vs. $81 \%$ for national products and $88 \%$ for regional products in the second TDS), food grouping appears to be an effective strategy to remain representative of the French diet, despite a limitation of means. The coverage of $90 \%$ of the French diet, and especially the inclusion in the sampling plan of the highest contributors to contaminant exposure or mineral intake, should lead to an accurate assessment of population exposure, which is the aim of a TDS. Nevertheless, one of the risks is to miss a contributor, whose consumption level could be low but whose contamination could be relatively high. Its contribution would then be significant. This is one of the reasons why, in this study, analyses have been provided for some foods that are not identified as high contributors to some contaminants. For example, POPs are known to accumulate in meat-based products; that will be analysed in fat products (oil, margarine and butter), meals and ready-to-eat products such as sandwiches.

This TDS will allow the creation of a food library consisting of freeze-dried individual food composites stored at $-25^{\circ} \mathrm{C}$, at least until the next French TDS. Those samples will be useful for further analyses if necessary. For example, other elements could be analysed in one or more samples within the framework of a potential sanitary problem. This point is essential for effective and quality-guaranteed food monitoring from a public health point of view. 


\section{References}

AFSSA (Agence Française de Sécurité Sanitaire des Aliments/French Food Safety Agency), AFSSE, IFEN. Observatoire des Résidus de Pesticides, Etude de faisabilité [Internet]. 2004. Observatoire des Résidus de Pesticides ; [cited 2008 June 2]. Available from: http://www.observatoirepesticides.gouv.fr/upload/bibliotheque/502821546671464415775317948618/etude faisabilite 30juin04.pdf [in French]

AFSSA (Agence Française de Sécurité Sanitaire des Aliments/French Food Safety Agency), 2005b. Sécurité et bénéfices des phyto-estrogènes apportés par l'alimentation Recommandations [in French].

Bemrah N, Leblanc JC, Volatier JL. 2008. Assessment of dietary exposure in the French population to 13 selected food colours, preservatives, antioxidants, stabilizers, emulsifiers and sweeteners. Food Addit Contam Part B. 1(1):2-14.

Codex Alimentarius Commission (CAC). 2005. Procedural Manual. CCFAC Guidelines for Exposure Assessment of Contaminants and Toxins in food or Food Groups, fifteenth edition, p. 114-117. Available from: http://www.fao.org/docrep/009/a0247e/a0247e04.htm

Committee on Toxicity of Chemicals in Food, Consumer Products and the Environment (COT). COT statement on twelve metals and other elements in the 2000 UK Total Diet Study (TDS) [Internet]. 2004. Food Standard Agency; [cited 2008 June 2]. Available from: http://www.food.gov.uk/multimedia/pdfs/cotstatements2004metals.pdf

Egan SK, Bolger PM, Carrington CD. 2007. Update of US FDA's Total Diet Study food list and diets. J Eposure Sci Environ Epidemiol. 17(6):573-582. 
European Commission. Corrigendum to Regulation (EC) No 850/2004 of the European Parliament and of the Council of 29 April 2004 on persistent organic pollutants and amending Directive 79/117/EEC [Internet]. 2004. European Commission; [cited 2008 June 2]. Available from: http://eur-lex.europa.eu/JOHtml.do?uri=OJ:L:2007:204:SOM:EN:HTML

INSEE: Institut National de la Statistique et des Études Économiques (National Institute for Statistics and Economic Studies). Les 57 unités urbaines de plus de 100000 habitants [in French] [Internet]. 1999. INSEE ; [cited 2008 June 2]. Available:

http://www.insee.fr/fr/ffc/chifcle fiche.asp?tab $i d=201$

JECFA (Joint FAO/WHO Expert Committee on Food Additives). 2005. 64th JECFA, Joint Expert FAO/WHO Expert Committee on Food Additives, Sixty-fourth meeting, Rome, 8-17 February 2005.

Lafay L, Mennen L, Six MA, Calamassi-Tran G, Hercberg S, Volatier JL, Castetbon K, Martin A. 2002. Étude de validation d'un carnet de consommation alimentaire de 7 jours pour l'enquête INCA 2-ENNS. Journées de Méthodologie Statistiques [in French] [Internet]. Available: http://jms.insee.fr/site/files/documents/2005/368 1-JMS2002 SESSION9 LAFAYET-ALII INCA2 ACTES.PDF

Le Moullec N, Deheeger M, Preziosi P, Montero P, Valeix P, Rolland-Cachera ME, Potier de Courcy G, Christides JP, Galan P, Hercberg S. 1996. Validation du manuel-photos utilisé pour l'enquête alimentaire de l'étude SUVIMAX. Cah Nutr Diet. 31:158-164.

Leblanc JC, Tard A, Volatier JL, Verger P. 2005a. Estimated dietary to principal food mycotoxins from the First French Total Diet Study. Food Addit Contam. 22:652-672. 
Leblanc JC, Guérin T, Noël L, Calamassi-Tran G, Volatier JL, Verger P. 2005b. Dietary exposure estimates of 18 elements from the 1st French Total Diet Study. Food Addit Contam. 22:624-641.

Leblanc JC, coordinator. CALIPSO - Fish and seafood consumption study and biomarker of exposure to trace elements, pollutants and omega 3 [Internet]. 2006. AFSSA; [cited 2008 June 2]. Available from: http://www.afssa.fr/Documents/PASER-Ra-CalipsoEN.pdf

Menard C, Heraud F, Nougadere A, Volatier JL, Leblanc JC. 2008. Relevance of integrating Agricultural Practices in Pesticides Dietary Intake Indicator. Food Chem Tox. 46: 3240-3253.

New Zealand Food Safety Authority (NZFSA). New Zealand Total Diet Survey report released [Internet]. 2006. NZFSA; [cited 2008 June 2]. Available from:

http://www.nzfsa.govt.nz/publications/media-releases/2006-02-24.htm

Peattie ME, Buss DH, Lindsay DG. 1983. Reorganization of the British total diet study for monitoring food constituents from 1981. Food Chem Toxicol. 21(4):503-507.

Pennington JAT. 1983. Revision of the Total Diet Study food list and diets. J Am Diet Assoc. 82:166-173.

Pennington JAT, Hernandez TB. 2002. Core foods of the US food supply. Food Addit Contam. 19(3):246-271.

Tard A, Gallotti S, Leblanc JC, Volatier JL. 2007. Dioxins, furans and dioxin-like PCBs: Occurrence in food and dietary intake in France. Food Addit Contam. 24(9):1007-1017. 
WHO. GEMS/Food. Guidelines for predicting dietary intake of pesticide residues (revised). Prepared by the Global Environment Monitoring System - Food Contamination Monitoring and Assessment Programme (GEMS / Food) in collaboration with the Codex Committee on Pesticide Residues WHO/FSF/FOS/97.7 [Internet]. 1997. WHO; [cited 2008 June 2]. Available from: http://www.who.int/

WHO. GEMS/Food Total Diet Studies. Report of a Joint USFDA/WHO: International Workshop on Total Diet Studies in cooperation with the Pan American Health Organization. Kansas City, MO, USA [Internet]. 1999. WHO; [cited 2008 June 2]. Available from: http://www.who.int/foodsafety/publications/chem/en/index.html

WHO/ANFZA/FAO. GEMS/Food Total Diet Studies. Report of a Joint USFDA/WHO: International Workshop on Total Diet Studies. Brisbane, Australia [Internet]. 2002. WHO; [cited 2008 June 2]. Available from:

http://www.who.int/foodsafety/publications/chem/en/index.html

WHO/INRA. GEMS/Food Total Diet Studies. Report of a Joint USFDA/WHO: International Workshop on Total Diet Studies. Paris, France [Internet]. 2004. WHO; [cited 2008 June 2]. Available from: http://www.who.int/foodsafety/publications/chem/en/index.html

WHO/CCDCP. GEMS/Food Total Diet Studies. Report of a Joint USFDA/WHO: International Workshop on Total Diet Studies. Bejing, China [Internet]. 2006. WHO; [cited 2008 June 2]. Available from: http://www.who.int/foodsafety/publications/chem/en/index.html 
Figure 1: Methodology of TDS sampling

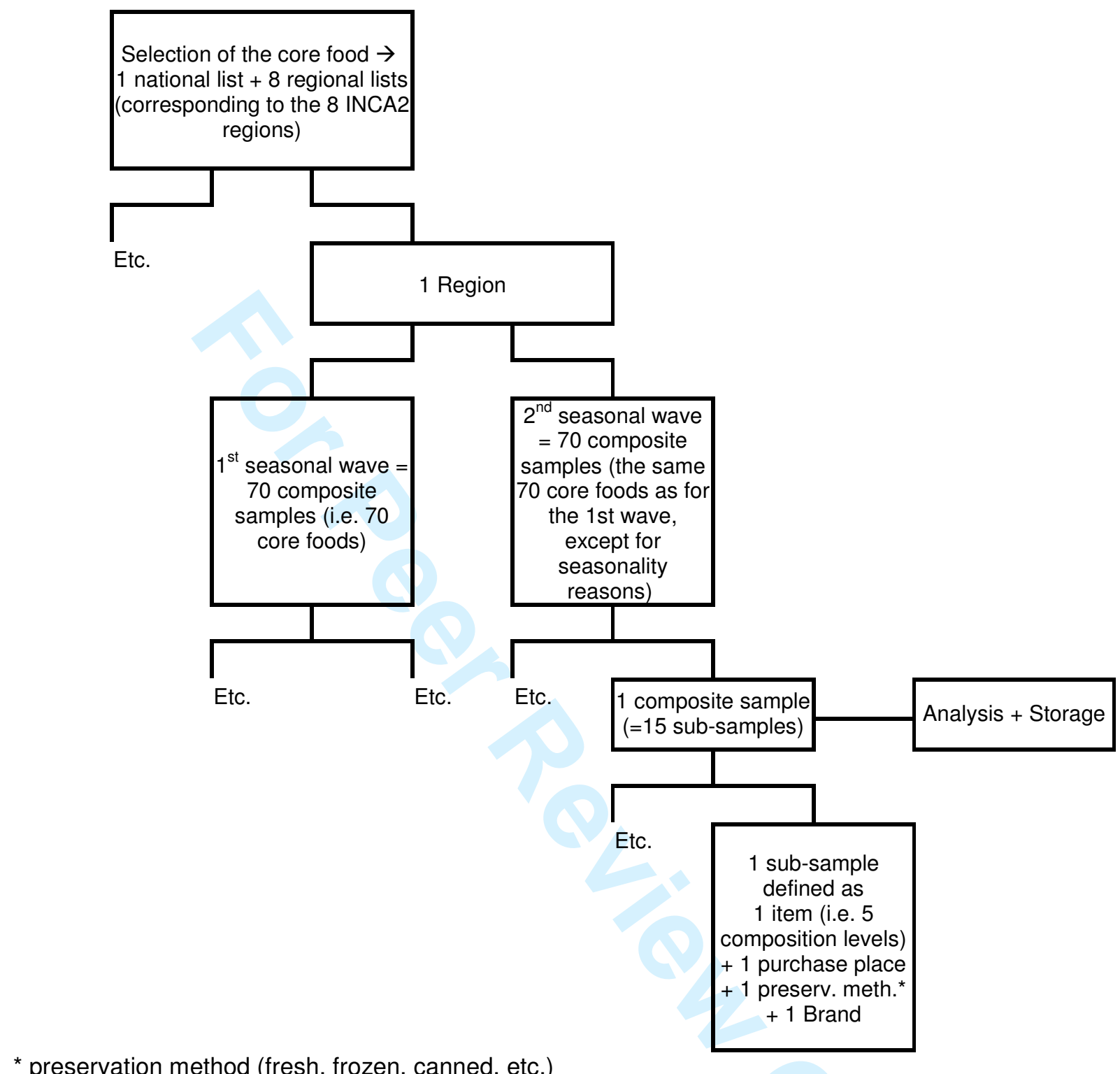

${ }^{*}$ preservation method (fresh, frozen, canned, etc.) 
4

5

Table 1: Examples of composition of 3 core food samples from sub-samples

\begin{tabular}{|c|c|c|c|c|c|c|}
\hline $\begin{array}{l}\text { Composite } \\
\text { sample }\end{array}$ & $\begin{array}{l}\text { Sub- } \\
\text { sample }\end{array}$ & $\begin{array}{l}\text { Level 1: } \\
\text { quantity } \\
\text { consumed }\end{array}$ & $\begin{array}{l}\text { Level 2: } \\
\text { texture or } \\
\text { manufacturi } \\
\text { ng process }\end{array}$ & $\begin{array}{l}\text { Level 3: fat, } \\
\text { salt or other } \\
\text { component } \\
\text { content }\end{array}$ & $\begin{array}{l}\text { Level 4: flavor } \\
\text { and/or origin }\end{array}$ & \begin{tabular}{|l|} 
Level 5: \\
product \\
specification \\
s \\
\end{tabular} \\
\hline \multirow{15}{*}{$\begin{array}{l}\text { Cocktail } \\
\text { biscuits }\end{array}$} & 1 & Crackers & - & - & Salted & - \\
\hline & 2 & Crackers & - & - & Salted & - \\
\hline & 3 & Crackers & - & - & Cheese & - \\
\hline & 4 & Crackers & - & - & Cheese & - \\
\hline & 5 & Biscuit & Extruded & - & Peanut & - \\
\hline & 6 & Biscuit & Extruded & - & Peanut & - \\
\hline & $x^{2}$ & Biscuit & Extruded & - & Bacon & - \\
\hline & 0 & Biscuit & "Soufflé" & - & Peanut & - \\
\hline & 9 & Biscuit & Filled & - & Cheese+other & - \\
\hline & 10 & Snack & - & - & Cheese & - \\
\hline & 11 & Snack & - & - & Salted & - \\
\hline & 12 & Snack & - & - & Salted & - \\
\hline & 13 & Chips & Tile shape & - & Paprika & - \\
\hline & 14 & Chips & Tile shape & - & Salted & - \\
\hline & 15 & Chips & Tortilla & - & Chili pepper & - \\
\hline \multirow{15}{*}{ Ice cream } & 1 & Ice cream & Box & - & Vanilla & - \\
\hline & 2 & Ice cream & Box & - & Vanilla & - \\
\hline & 3 & Ice cream & Box & - & Chocolate & - \\
\hline & 4 & Ice cream & Box & - & Coffee & - \\
\hline & 5 & Ice cream & Cornet & - & Vanilla & - \\
\hline & 6 & Ice cream & Cornet & - & Vanilla & - \\
\hline & 7 & Ice cream & Cornet & - & Chocolate & - \\
\hline & 8 & Ice cream & Cornet & - & Chocolate & - \\
\hline & 9 & Ice cream & Stick & - & Vanilla & - \\
\hline & 10 & Ice cream & Stick & - & Vanilla & - \\
\hline & 11 & Ice cream & Stick & - & Vanilla & - \\
\hline & 12 & Ice cream & Bar & $-\quad$ & - & - \\
\hline & 13 & Ice cream & Pot & $-\quad$ & Mixed & - \\
\hline & 14 & Water ice & Box & $-\quad$ & Lemon & - \\
\hline & 15 & Water ice & Box & $-\quad-\quad$ & Lemon & - \\
\hline \multirow{15}{*}{$\begin{array}{l}\text { Camembert*- } \\
\text { type cheese }\end{array}$} & 1 & Camembert & & $40 \%$ fat & Normandy & - \\
\hline & 2 & Camembert & & $45 \%$ fat & Normandy & \begin{tabular}{|l|} 
"AOC" \\
(Quality- \\
controlled \\
designation \\
of origin) \\
\end{tabular} \\
\hline & 3 & Camembert & & $45 \%$ fat & Normandy & - \\
\hline & 4 & Camembert & & $45 \%$ fat & Normandy & - \\
\hline & 5 & Camembert & & $45 \%$ fat & Normandy & - \\
\hline & 6 & Camembert & & $45 \%$ fat & Normandy & - \\
\hline & 7 & Camembert & & $50 \%$ fat & Normandy & - \\
\hline & 8 & Camembert & & $50 \%$ fat & Normandy & - \\
\hline & 9 & Camembert & & $50 \%$ fat & Normandy & - \\
\hline & 10 & Camembert & & $50 \%$ fat & Normandy & - \\
\hline & 11 & Camembert & & $20-30 \%$ fat & Normandy & “Light” \\
\hline & 12 & $\begin{array}{ll}\begin{array}{l}\text { Caprice } \\
\text { dieux }\end{array} & \text { des } \\
\end{array}$ & & - & - & - \\
\hline & 13 & Coulommiers* & & - & Lorraine & - \\
\hline & 14 & Brie $^{*}$ & & $60 \%$ fat & - & - \\
\hline & 15 & Pavé & & - & - & - \\
\hline
\end{tabular}


Table 2: Selection of the cities for core food sampling.

\begin{tabular}{|c|c|c|c|}
\hline Region group & Regions & Sampling waves & Visiting cities \\
\hline \multirow[t]{2}{*}{$\mathrm{i}$} & $\begin{array}{l}\text { Brittany } \\
\text { Pays de Loire } \\
\text { Poitou-Charentes }\end{array}$ & $\begin{array}{l}1^{\text {st }} \text { : December } 2007 \text { to } \\
\text { February } 2008\end{array}$ & Rennes, Poitiers \\
\hline & & $\begin{array}{l}2^{\text {nd }}: \text { August to September } \\
2008\end{array}$ & Nantes, Brest \\
\hline \multirow[t]{2}{*}{ ii } & $\begin{array}{l}\text { Lower Normandy } \\
\text { Upper Normandy } \\
\text { Nord-Pas de Calais } \\
\text { Picardy }\end{array}$ & $1^{\text {st: }}:$ January to February 2008 & Caen, Lille \\
\hline & & $\begin{array}{l}2^{\text {nd }}: \text { August to September } \\
2008\end{array}$ & Rouen, Amiens \\
\hline iii & Ile de France & $\begin{array}{l}1^{\text {st }} \text { August to October } 2007 \\
2^{\text {nd }}: \text { March to April } 2008\end{array}$ & $\begin{array}{l}\text { Paris, Pontoise } \\
\text { Paris, Melun }\end{array}$ \\
\hline \multirow[t]{2}{*}{ iv } & $\begin{array}{l}\text { Champagne Ardennes } \\
\text { Lorraine } \\
\text { Alsace }\end{array}$ & $1^{\text {st: }}$ July to August 2008 & Reims, Metz \\
\hline & & $\begin{array}{l}2^{\text {nd }} \text { : December } 2008 \text { to } \\
\text { January } 2009\end{array}$ & Strasbourg, Nancy \\
\hline \multirow[t]{2}{*}{$\mathrm{v}$} & $\begin{array}{l}\text { Franche-Comté } \\
\text { Rhône Alpes }\end{array}$ & $1^{\text {st: }}$ May to June 2008 & Besançon, Lyon \\
\hline & 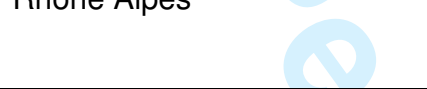 & $\begin{array}{l}2^{\text {nd }}: \text { October to December } \\
2008\end{array}$ & Saint-Etienne, Grenoble \\
\hline \multirow[t]{2}{*}{ vi } & $\begin{array}{l}\text { Provence Alpes Côte d'Azur } \\
\text { Languedoc Roussillon }\end{array}$ & $1^{\text {st }}:$ June to August 2007 & Marseilles, Perpignan \\
\hline & & $2^{\text {nd }}:$ February to April 2008 & Nice, Montpellier \\
\hline \multirow[t]{2}{*}{ vii } & $\begin{array}{l}\text { Midi-Pyrénées } \\
\text { Aquitaine }\end{array}$ & $1^{\text {st: }}$ April to May 2008 & Toulouse, Bordeaux \\
\hline & & $\begin{array}{l}2^{\text {nd }} \text { : September to October } \\
2008\end{array}$ & Pau, Montauban \\
\hline \multirow[t]{2}{*}{ viii } & $\begin{array}{l}\text { Centre } \\
\text { Bourgogne } \\
\text { Limousin } \\
\text { Auvergne }\end{array}$ & $1^{\text {st: }}$ April to May 2008 & Orleans, Dijon \\
\hline & & $\begin{array}{l}2^{\text {nd }} \text { : October to November } \\
2008\end{array}$ & Limoges, Clermont-Ferrand \\
\hline ix & National & $\begin{array}{l}1^{\text {st }}: \text { October } 2007 \text { to January } \\
2008 \\
2^{\text {nd }}: \text { June to July } 2008\end{array}$ & $\begin{array}{l}\text { Paris } \\
\text { Paris }\end{array}$ \\
\hline
\end{tabular}


Table 3: Selection of regional core foods for the eight regions.

\begin{tabular}{|c|c|c|c|c|c|c|}
\hline Food group & Core food prepared "as consumed" & $\begin{array}{c}\mathrm{Nb} \\
\text { regions } \\
\text { sampled }\end{array}$ & $\begin{array}{c}\text { Mean } \\
\text { adult } \\
\text { consumer } \\
\text { rate }\end{array}$ & $\begin{array}{c}\text { Mean \% } \\
\text { of diet } \\
\text { among } \\
\text { adults }\end{array}$ & $\begin{array}{c}\text { Mean } \\
\text { children } \\
\text { consumer } \\
\text { rate }\end{array}$ & $\begin{array}{l}\text { Mean \% } \\
\text { of diet } \\
\text { among } \\
\text { children }\end{array}$ \\
\hline Coffee & Coffee, black, unsweetened & 8 & 62,5 & 11,1 & 3,36 & 0,27 \\
\hline Coffee & $\begin{array}{l}\text { Coffee, instant } \\
\text { Ravioli or Lasagnas with meat and tomato }\end{array}$ & 8 & 6,48 & 0,58 & 0,00 & 0,00 \\
\hline Cooked dishes & sauce & 8 & 20,2 & 0,58 & 32,1 & 1,21 \\
\hline Cooked dishes & Couscous, cooked & 5 & 9,88 & 0,47 & 11,2 & 0,58 \\
\hline Cooked dishes & Sauerkraut with meat & 3 & 7,95 & 0,41 & 8,44 & 0,46 \\
\hline Cooked dishes & Boiled beef with vegetables & 4 & 6,78 & 0,35 & 8,82 & 0,47 \\
\hline Cooked dishes & Cassoulet & 2 & 9,81 & 0,30 & 10,9 & 0,36 \\
\hline Cooked dishes & Ratatouille & 4 & 15,4 & 0,29 & 15,0 & 0,31 \\
\hline Cooked dishes & Shepherd's pie & 5 & 7,25 & 0,24 & 11,7 & 0,45 \\
\hline Cooked dishes & Paella & 1 & 6,21 & 0,19 & 7,55 & 0,45 \\
\hline Cooked dishes & $\begin{array}{l}\text { Crepe with cheese, ham or chicken, cooked } \\
\text { Poultry Cordon Bleu, Filled with Cheese and }\end{array}$ & 4 & 10,6 & 0,16 & 17,6 & 0,42 \\
\hline Cooked dishes & Ham & 1 & 7,23 & 0,09 & 23,3 & 0,33 \\
\hline Cooked meats & Ham, cooked & 8 & 57,8 & 0,55 & 61,1 & 0,67 \\
\hline Cooked meats & Pâté & 7 & 30,7 & 0,27 & 26,5 & 0,20 \\
\hline Cooked meats & Ham, raw, cured & 6 & 23,6 & 0,18 & 14,1 & 0,12 \\
\hline Cooked meats & Spicy North African sausage & 3 & 13,2 & 0,13 & 14,7 & 0,18 \\
\hline Cooked meats & Dry sausage & 8 & 23,3 & 0,13 & 32,0 & 0,26 \\
\hline Cooked meats & Pork fat, raw & 2 & 22,8 & 0,11 & 17,0 & 0,11 \\
\hline Cooked meats & Chipolata sausage, cooked & 1 & 9,32 & 0,08 & 15,1 & 0,15 \\
\hline Cooked meats & Strasbourg sausage & 4 & 7,84 & 0,07 & 19,3 & 0,21 \\
\hline Cooked meats & Foie gras, canned & 1 & 12,1 & 0,07 & 12,8 & 0,11 \\
\hline Eggs & Egg, scrambled, butter & 8 & 34,7 & 0,51 & 34,3 & 0,56 \\
\hline Eggs & Egg, hard-boiled & 7 & 30,9 & 0,27 & 28,4 & 0,29 \\
\hline Fish & Salmon, steamed & 8 & 12,6 & 0,19 & 9,24 & 0,15 \\
\hline Fish & Fish cakes, fried & 8 & 14,8 & 0,18 & 32,3 & 0,46 \\
\hline Fish & Tuna, oven cooked & 1 & 5,59 & 0,14 & 0,00 & 0,00 \\
\hline Fish & Tuna, canned in oil or brine, drained & 2 & 16,8 & 0,11 & 17,3 & 0,11 \\
\hline Fish & Salmon, smoked & 1 & 18,1 & 0,10 & 17,4 & 0,08 \\
\hline Fish & Pollack, cooked & 3 & 6,76 & 0,09 & 9,92 & 0,15 \\
\hline Flan type dessert & $\begin{array}{l}\text { Flan with egg } \\
\text { Batter pudding, with fruits, commercial or }\end{array}$ & 6 & 9,54 & 0,22 & 10,3 & 0,34 \\
\hline Flan type dessert & home made & 2 & 3,48 & 0,09 & 5,05 & 0,27 \\
\hline Fruits & Apple, with skin, raw & 8 & 50,3 & 2,92 & 45,7 & 1,81 \\
\hline Fruits & Apricot, raw & 1 & 15,5 & 0,68 & 13,0 & 0,26 \\
\hline Fruits & Melon, raw & 8 & 11,6 & 0,53 & 10,3 & 0,57 \\
\hline Fruits & Strawberry, raw & 8 & 15,5 & 0,48 & 15,6 & 0,43 \\
\hline Fruits & Pear, flesh and skin, raw & 8 & 15,7 & 0,44 & 14,2 & 0,37 \\
\hline Fruits & Peach, flesh and skin, raw & 8 & 8,60 & 0,37 & 6,76 & 0,19 \\
\hline Fruits & Cherry, raw & 7 & 8,10 & 0,30 & 7,79 & 0,25 \\
\hline Fruits & Grape, white, raw & 8 & 3,76 & 0,09 & 2,47 & 0,07 \\
\hline Hot drinks & $\begin{array}{l}\text { Tea, unsweetened, or Infusion } \\
\text { Chocolate flavored beverage, sweetened, }\end{array}$ & 8 & 37,3 & 6,60 & 12,4 & 0,97 \\
\hline Hot drinks & prepared & 7 & 7,78 & 0,46 & 10,5 & 0,89 \\
\hline Hot drinks & $\begin{array}{l}\text { Chocolate flavored beverage base } \\
\text { Beef, steak, sirloin steak, or rib steak, broiled }\end{array}$ & 2 & 17,2 & 0,08 & 50,5 & 0,42 \\
\hline Meat & or braised & 8 & 68,0 & 1,43 & 72,6 & 1,78 \\
\hline
\end{tabular}




\begin{tabular}{|c|c|c|c|c|c|c|}
\hline Food group & Core food prepared "as consumed" & $\begin{array}{c}\mathrm{Nb} \\
\text { regions } \\
\text { sampled }\end{array}$ & $\begin{array}{c}\text { Mean } \\
\text { adult } \\
\text { consumer } \\
\text { rate }\end{array}$ & $\begin{array}{c}\text { Mean \% } \\
\text { of diet } \\
\text { among } \\
\text { adults }\end{array}$ & $\begin{array}{c}\text { Mean } \\
\text { children } \\
\text { consumer } \\
\text { rate }\end{array}$ & $\begin{array}{l}\text { Mean \% } \\
\text { of diet } \\
\text { among } \\
\text { children }\end{array}$ \\
\hline Meat & Pork chop, broiled or braised & 8 & 27,8 & 0,46 & 24,8 & 0,47 \\
\hline Meat & Pork roast, lean \& fat, cooked & 8 & 24,1 & 0,34 & 25,6 & 0,37 \\
\hline Meat & Veal, cooked & 8 & 18,9 & 0,26 & 15,8 & 0,24 \\
\hline Meat & Mutton & 8 & 16,6 & 0,25 & 13,8 & 0,21 \\
\hline Milk & Semi-skimmed milk & 8 & 48,6 & 4,67 & 76,4 & 14,8 \\
\hline Milk & Skimmed milk & 5 & 5,56 & 0,54 & 3,72 & 0,38 \\
\hline $\begin{array}{l}\text { Milk } \\
\text { Mollusks and }\end{array}$ & Whole milk & 6 & 3,04 & 0,26 & 8,95 & 1,57 \\
\hline $\begin{array}{l}\text { crustaceans } \\
\text { Mollusks and }\end{array}$ & Oyster, raw & 5 & 4,71 & 0,22 & 1,33 & 0,12 \\
\hline $\begin{array}{l}\text { crustaceans } \\
\text { Mollusks and }\end{array}$ & Mussel, boiled & 5 & 5,25 & 0,15 & 5,49 & 0,17 \\
\hline $\begin{array}{l}\text { crustaceans } \\
\text { Mollusks and }\end{array}$ & Shrimp or prawn, boiled & 8 & 14,2 & 0,14 & 11,3 & 0,18 \\
\hline $\begin{array}{l}\text { crustaceans } \\
\text { Offals }\end{array}$ & Scallop, steamed & 3 & $\begin{array}{l}6,74 \\
701\end{array}$ & 0,07 & 4,78 & $\begin{array}{l}0,08 \\
0,04\end{array}$ \\
\hline $\begin{array}{l}\text { Offals } \\
\text { Potato-based } \\
\text { products }\end{array}$ & Liver, cooked & 8 & 7,91 & 0,08 & 4,05 & 0,04 \\
\hline $\begin{array}{l}\text { products } \\
\text { Potato-based } \\
\text { products }\end{array}$ & $\begin{array}{l}\text { Potato, boiled } \\
\text { Potato chip or French fry, cooked or sauted }\end{array}$ & 8 & 51,6 & 1,45 & 52,0 & 1,66 \\
\hline $\begin{array}{l}\text { Potato-based } \\
\text { products } \\
\text { Potato-based }\end{array}$ & Mashed potato & 8 & 34,4 & 0,67 & 46,4 & 1,27 \\
\hline products & Potato crisp or chip, salted & 8 & 12,7 & 0,04 & 23,9 & 0,10 \\
\hline Poultry & Chicken, roasted & 8 & 48,4 & 1,22 & 58,0 & 1,41 \\
\hline Poultry & Duck, cooked & 2 & 17,9 & 0,23 & 18,1 & 0,27 \\
\hline Poultry & Turkey, breast, sauted or roasted & 8 & 17,9 & 0,20 & 20,5 & 0,30 \\
\hline Poultry & Turkey, roasted & 1 & 9,58 & 0,13 & 15,1 & 0,45 \\
\hline Sandwiches & Sandwich & 8 & 21,2 & 0,50 & 15,9 & 0,35 \\
\hline Sandwiches & Hamburger & 7 & 12,5 & 0,32 & 17,4 & 0,43 \\
\hline Soups & Vegetable soup & 8 & 33,9 & 3,01 & 29,9 & 2,38 \\
\hline Soups & Chicken noodle soup & 1 & 14,3 & 0,49 & 9,43 & 0,36 \\
\hline $\begin{array}{l}\text { Starter, entrée } \\
\text { Ultra-fresh dairy }\end{array}$ & Taboule, canned & 3 & 12,6 & 0,15 & 15,6 & 0,22 \\
\hline $\begin{array}{l}\text { products } \\
\text { Ultra-fresh dairy }\end{array}$ & Yogurt, part.-skimmed & 8 & 47,4 & 1,80 & 58,2 & 2,70 \\
\hline $\begin{array}{l}\text { products } \\
\text { Ultra-fresh dairy }\end{array}$ & Yogurt, whole milk & 8 & 29,4 & 1,03 & 34,6 & 1,48 \\
\hline $\begin{array}{l}\text { products } \\
\text { Ultra-fresh dairy }\end{array}$ & Fromage blanc & 8 & 29,1 & 0,69 & 43,7 & 1,27 \\
\hline $\begin{array}{l}\text { products } \\
\text { Ultra-fresh dairy }\end{array}$ & Nonfat yogurt & 8 & 16,2 & 0,66 & 6,66 & 0,23 \\
\hline products & Milk, buttermilk, fluid, cultured & 8 & 4,18 & 0,14 & 21,7 & 0,99 \\
\hline Vegetables & Tomato, raw or cooked & 8 & 51,8 & 0,87 & 49,5 & 0,93 \\
\hline Vegetables & Beans, boiled & 8 & 51,8 & 0,84 & 60,8 & 1,07 \\
\hline Vegetables & Salad & 8 & 73,2 & 0,75 & 51,3 & 0,41 \\
\hline Vegetables & Carrot, raw or boiled & 8 & 46,8 & 0,62 & 46,2 & 0,70 \\
\hline Vegetables & Pea, boiled, W/O salt & 8 & 27,7 & 0,38 & 29,5 & 0,46 \\
\hline Vegetables & Chicory (Belgian endive), raw or boiled & 8 & 28,7 & 0,36 & 12,1 & 0,08 \\
\hline Vegetables & Lentil, boiled & 8 & 14,4 & 0,29 & 18,8 & 0,40 \\
\hline Vegetables & Spinach, steamed & 8 & 14,4 & 0,24 & 14,1 & 0,21 \\
\hline
\end{tabular}




\begin{tabular}{|c|c|c|c|c|c|c|}
\hline Food group & Core food prepared "as consumed" & $\begin{array}{l}\mathrm{Nb} \\
\text { regions } \\
\text { sampled }\end{array}$ & $\begin{array}{c}\text { Mean } \\
\text { adult } \\
\text { consumer } \\
\text { rate }\end{array}$ & $\begin{array}{c}\text { Mean \% } \\
\text { of diet } \\
\text { among } \\
\text { adults }\end{array}$ & $\begin{array}{c}\text { Mean } \\
\text { children } \\
\text { consumer } \\
\text { rate }\end{array}$ & $\begin{array}{c}\text { Mean \% } \\
\text { of diet } \\
\text { among } \\
\text { children }\end{array}$ \\
\hline Vegetables & Courgette (zucchini), boiled & 8 & 14,6 & 0,23 & 12,8 & 0,17 \\
\hline Vegetables & Cauliflower, boiled & 8 & 12,0 & 0,21 & 12,3 & 0,26 \\
\hline Vegetables & Cucumber, raw & 6 & 16,7 & 0,21 & 16,4 & 0,28 \\
\hline Vegetables & Artichoke, globe, boiled, W/O salt & 8 & 6,00 & 0,20 & 5,20 & 0,18 \\
\hline Vegetables & Radish with leaves, raw & 6 & 12,6 & 0,13 & 6,74 & 0,06 \\
\hline Vegetables & Leek, boiled & 8 & 8,91 & 0,10 & 4,23 & 0,04 \\
\hline Vegetables & Corn, sweet & 8 & 12,5 & 0,09 & 19,1 & 0,14 \\
\hline Vegetables & Onion, raw or boiled & 8 & 22,9 & 0,08 & 16,8 & 0,05 \\
\hline Vegetables & Celeriac, boiled & 1 & 8,06 & 0,06 & 3,37 & 0,01 \\
\hline Vegetables & Pepper, sweet, raw or boiled & 5 & 6,85 & 0,05 & 4,34 & 0,03 \\
\hline Vegetables & Haricot bean, boiled & 1 & 1,57 & 0,03 & 7,69 & 0,56 \\
\hline Vegetables & Turnip, boiled & 8 & 2,45 & 0,03 & 1,84 & 0,02 \\
\hline Vegetables & Celery stalk, boiled & 5 & 2,25 & 0,03 & 1,38 & 0,02 \\
\hline Water & Tap water & 8 & 72,2 & 23,5 & 79,7 & 24,2 \\
\hline Water & Spring water, bottled & 8 & 36,5 & 8,98 & 45,4 & 11,2 \\
\hline
\end{tabular}


Table 4: Selection of national core foods.

\begin{tabular}{|c|c|c|c|c|c|}
\hline Food group & Core food prepared "as consumed" & $\begin{array}{l}\text { Adult } \\
\text { consumer } \\
\text { rate }\end{array}$ & $\begin{array}{l}\% \text { of diet } \\
\text { among } \\
\text { adults }\end{array}$ & $\begin{array}{ll}\text { Children } \\
\text { consumer } \\
\text { rate }\end{array}$ & $\begin{array}{l}\text { \% of diet } \\
\text { among } \\
\text { children }\end{array}$ \\
\hline Alcoholic beverages & Wine & 47.1 & 6.98 & 2.06 & 0.05 \\
\hline Alcoholic beverages & Beers & 16.3 & 2.56 & 0.37 & 0.03 \\
\hline Alcoholic beverages & Champagne & 12.3 & 0.51 & 0.74 & 0.03 \\
\hline Alcoholic beverages & Pastis & 7.83 & 0.52 & 0.00 & 0.00 \\
\hline Alcoholic beverages & Cider & 5.86 & 0.37 & 0.93 & 0.05 \\
\hline Biscuits & Biscuit & 23.4 & 0.24 & 31.2 & 0.37 \\
\hline Biscuits & Chocolate biscuits/cookies & 19.8 & 0.38 & 53.6 & 1.51 \\
\hline Biscuits & Crackers & 18.4 & 0.12 & 20.0 & 0.16 \\
\hline Biscuits & Moist cake & 15.5 & 0.31 & 24.3 & 0.62 \\
\hline $\begin{array}{l}\text { Biscuits } \\
\text { Biscuits }\end{array}$ & $\begin{array}{l}\text { Fruit cake } \\
\text { Moist chocolate cake }\end{array}$ & $\begin{array}{l}6.78 \\
4.41\end{array}$ & $\begin{array}{l}0.11 \\
0.06\end{array}$ & $\begin{array}{l}7.42 \\
13.7\end{array}$ & $\begin{array}{l}0.14 \\
0.27\end{array}$ \\
\hline Biscuits & Jam filled biscuit & 1.05 & 0.01 & 5.75 & 0.08 \\
\hline Bread and rusk & French bread (baguette) & 89.5 & 7.94 & 89.2 & 5.77 \\
\hline Bread and rusk & Rusk & 27.1 & 0.36 & 25.2 & 0.23 \\
\hline Bread and rusk & Farmhouse loaf & 22.0 & 1.13 & 14.8 & 0.47 \\
\hline Bread and rusk & Sandwich loaf & 15.3 & 0.38 & 28.4 & 0.76 \\
\hline Bread and rusk & Wholemeal bread & 11.9 & 0.42 & 8.16 & 0.17 \\
\hline Bread and rusk & Toasts & 11.5 & 0.32 & 8.72 & 0.2 \\
\hline Bread and rusk & Cereal bread & 8.95 & 0.27 & 6.49 & 0.13 \\
\hline Butter & Butter & 68.0 & 0.86 & 74.2 & 1.11 \\
\hline Butter & Salted butter & 19.8 & 0.26 & 21.5 & 0.34 \\
\hline Butter & Low-fat butter & 19.0 & 0.19 & 17.1 & 0.13 \\
\hline Cereals for breakfast & Chocolate cereals for breakfast & 7.18 & 0.18 & 34.3 & 0.96 \\
\hline Cereals for breakfast & Cornflakes & 4.67 & 0.1 & 18.4 & 0.47 \\
\hline \multicolumn{6}{|l|}{ Cereals for breakfast } \\
\hline & Muesli & 4.28 & 0.13 & 4.64 & 0.14 \\
\hline Cheese & Camembert cheese & 45.9 & 0.94 & 34.9 & 0.60 \\
\hline Cheese & Gruyère cheese & 43.6 & 0.44 & 44.5 & 0.43 \\
\hline Cheese & Goat cheeses & 29.8 & 0.36 & 20.8 & 0.26 \\
\hline Cheese & Cantal-type cheeses & 26.3 & 0.38 & 23.0 & 0.43 \\
\hline Cheese & Cheese spreads & 14.3 & 0.13 & 30.8 & 0.38 \\
\hline Cheese & Roquefort-type cheese & 11.5 & 0.13 & 3.71 & 0.04 \\
\hline Cheese & Edam-type cheese & 7.31 & 0.08 & 9.28 & 0.10 \\
\hline Cheese & Babybel-type cheese & 2.30 & 0.02 & 10.2 & 0.13 \\
\hline Chocolate & Dark chocolate & 33.7 & 0.26 & 32.7 & 0.27 \\
\hline Chocolate & Milk chocolate & 7.77 & 0.05 & 18.2 & 0.19 \\
\hline Chocolate & Hazelnut/almond chocolate & 6.65 & 0.05 & 10.8 & 0.06 \\
\hline $\begin{array}{l}\text { Chocolate } \\
\text { Compotes and stewed fruits }\end{array}$ & $\begin{array}{l}\text { Chocolate-bar with biscuit } \\
\text { Canned apple compote }\end{array}$ & $\begin{array}{l}3.42 \\
12.7\end{array}$ & $\begin{array}{l}0.04 \\
0.43\end{array}$ & $\begin{array}{l}10.2 \\
18.9\end{array}$ & $\begin{array}{l}0.13 \\
0.65\end{array}$ \\
\hline Compotes and stewed fruits & Canned fruits with syrup & 10.1 & 0.30 & 14.8 & 0.48 \\
\hline Compotes and stewed fruits & Canned compote (other than apple) & 10.0 & 0.30 & 21.0 & 0.91 \\
\hline Compotes and stewed fruits & Low-sugar fruit compotes & 5.73 & 0.25 & 8.16 & 0.33 \\
\hline Condiments and sauces & Vinaigrette & 61.1 & 0.72 & 51.6 & 0.58 \\
\hline Condiments and sauces & Tomato sauce & 22.5 & 0.20 & 23.8 & 0.25 \\
\hline Condiments and sauces & Ketchup & 7.70 & 0.09 & 22.5 & 0.25 \\
\hline Condiments and sauces & Soy sauce & 1.45 & 0.01 & 1.30 & 0.01 \\
\hline
\end{tabular}


Condiments and sauces

Mayonnaise

Condiments and sauces

Tomato sauce with meat

Cooked dishes

Soya "escalope" (imitation meat)

Dessert

Dessert

Crème dessert

Chocolate mousse

Dessert

Dessert

Crème caramel

Chocolate cream topped with

crème Chantilly

Dessert

Plain Soya-based dessert

Dessert

Soya-based dessert with fruit

Soya-based dessert with chocolate

Dessert

Dried vegetable

Tofu

Fruit

Banana

Fruit

Fruit

Fruit

Fruit

Ice cream

Margarine

Margarine

Nuts and oilseeds

Nuts and oilseeds

Oil

Oil

Oil

Oil

Oil

\section{Pasta}

Pasta

Pastries

Pastries

Pastries

Pastries

Pastries

Pastries

Pastries

Pizzas, quiches and salted cakes

Pizzas, quiches and salted cakes

Rice and semolina

Rice and semolina

Rice and semolina

Soft drinks

Soft drinks

Soft drinks

Soft drinks

Soft drinks

Soft drinks

Soft drinks

Soft drinks

Soft drinks

Soft drinks

Soft drinks

9.15

0.59

25.0

8.43

4.67

3.88

1.65

1.51

0.39

0.26

34.4

27.2

19.2

15.3

7.11

25.8

24.3

10.5

21.8

9.87

54.9

28.2

25.6

9.87

0.20

75.0

4.67

29.8

16.5

14.6

13.8

13.6

5.20

2.70

36.1

13.9

56.2

8.89

6.06

32.5

30.9

11.0

4.94

4.67

4.41

4.28

4.02

3.82

2.90

2.37
0.10

0.10

$$
0.01
$$

1.04

0.22

0.11

0.12

0.07

0.08

0.01

0.01

1.76

1.36

1.35

0.67

0.25

0.66

0.29

0.1

0.22

0.11

0.64

0.26

0.19

0.06

0.00

3.95

0.14

1.15

0.34

0.69

0.48

0.38

0.10

0.08

1.59

0.31

2.13

0.25

0.11

3.38

5.11

0.85

0.42

0.38

0.41

0.53

0.62

0.34

0.16

0.21
27.8

0.16

11.5

0.37

43.6

12.8

5.01

6.68

0.74

0.74

0.37

0.00

39.2

28.6

12.2

17.6

5.94

38.0

21.0

8.72

15.0

5.01

50.7

31.7

23.6

7.79

0.00

87.6

6.86

20.8

23.0

17.4

26.2

14.1

6.31

6.68

42.9

14.7

60.7

16.7

10.4

45.8

51.6

13.4

13.5

11.0

12.8

11.0

7.98

7.05

2.97

8.72
0.15

0.01

2.57

0.42

0.14

0.29

0.01

0.03

0.02

0.00

2.10

1.30

0.65

0.72

0.18

1.28

0.21

0.10

0.16

0.04

0.65

0.37

0.20

0.07

0.00

5.78

0.21

0.85

0.56

0.94

1.13

0.43

0.14

0.21

1.71

0.41

2.42

0.50

0.23

6.32

7.82

1.08

1.14

1.18

1.46

1.06

1.30

0.80

0.29

0.86 
Soft drinks

Soft drinks

Soup

Soup

Sugar and sugar-based products

Sugar and sugar-based products

Sugar and sugar-based products

Sugar and sugar-based products Sugar and sugar-based products Vegetable

Viennese bread and buns

Viennese bread and buns

Viennese bread and buns

Water

Water

Water

Water

Water

Water

Water
Grape juice

Soya milk

Cartonned soup

Cartonned tomato-soup

Sugar, white or brown

Jam or Marmalade

Chocolate spread

Honey

Sweets, candies

Canned bean sprouts

Brioche

Chocolate-filled pastry

Croissant

Evian water

Vittel water

Contrex water

Volvic water

Hépar water

Badoit water

Perrier water
1.58

1.51

0.16

5.75

0.31

14.7

0.17

0.74

0.13

3.42

1.34

18.9

1.49

65.4

0.22

5.01

0.45

41.6

0.73

60.3

0.40

14.8

0.88

35.1

0.64

14.0

0.24

45.5

0.84

12.8

0.15

8.35

37.1

0.08

$1.78 \quad 0.02$

1.11

0.31

$27.7 \quad 0.64$

47.1

0.01

$19.8 \quad 0.41$

34.1

1.22

10.0

0.19

11.0

0.77

12.2

3.37

11.9

0.25

8.49

2.2

4.64

2.32

6.52

2.88

2.23

0.89

6.32

1.81

7.61

0.54

5.00

1.56

1.67

1.21

4.54

0.93

1.48

0.12

4.54

1.86 
Table 5: Examples of international sampling for TDS

\begin{tabular}{|c|c|c|c|c|c|c|c|}
\hline $\begin{array}{l}\text { Countries } \\
\text { (start) }\end{array}$ & $\begin{array}{l}\text { Number of } \\
\text { Foods } \\
\text { (food list) }\end{array}$ & Frequency & $\begin{array}{c}\text { Number } \\
\text { of } \\
\text { Seasons }\end{array}$ & $\begin{array}{l}\text { Number of } \\
\text { Regions / } \\
\text { Cities }\end{array}$ & $\begin{array}{l}\text { Total number } \\
\text { of composite } \\
\text { Samples (or } \\
\text { individual } \\
\text { samples) }\end{array}$ & $\begin{array}{l}\text { Number of } \\
\text { Sub- } \\
\text { samples per } \\
\text { composite } \\
\text { sample }\end{array}$ & $\begin{array}{c}\text { Number of } \\
\text { total } \\
\text { purchased } \\
\text { individual } \\
\text { samples }\end{array}$ \\
\hline France (2000) & 200 & $\begin{array}{l}\text { 6-year } \\
\text { period }\end{array}$ & 2 & $8 / 36$ & 1,352 & 15 & 20,380 \\
\hline USA (1961) & 280 & $\begin{array}{l}1 \text {-year } \\
\text { period }\end{array}$ & 4 & $4 / 12$ & 1,120 & 3 & 3,360 \\
\hline Australia (1970) & 59 & $\begin{array}{l}\text { 1-year } \\
\text { period }\end{array}$ & 1 & 8 & 687 & 3 & 2,061 \\
\hline Czech Rep (1994) & 143 & $\begin{array}{l}\text { 1-2-year } \\
\text { period }\end{array}$ & 4 & $4 / 12$ & $880(143)$ & na & 3696 \\
\hline New Zealand (1987) & 121 & $\begin{array}{l}5 \text {-year } \\
\text { period }\end{array}$ & 2 & 4 & 968 & na & na \\
\hline China (1990) & na & $\begin{array}{l}\text { 2-8-year- } \\
\text { period }\end{array}$ & 1 & $4 / 144$ & $48(662)$ & $3-4$ & 2030 \\
\hline UK (1966) & 119 & $\begin{array}{l}\text { 1-year } \\
\text { period }\end{array}$ & 4 & 20 & 20 & 20 & 400 \\
\hline Canada (1969) & 200 & $\begin{array}{l}1 \text {-year } \\
\text { period }\end{array}$ & 1 & $-/ 4$ & 200 & $3-6$ & $600-1,200$ \\
\hline
\end{tabular}

na: not available 